\title{
The Electrosensory Periphery: a Comparative Study of Weakly Electric Fish.
}

\author{
M. Castello ${ }^{1 *}$, V. Campbel1 ${ }^{1}$, M. Figares ${ }^{1}$, A. Pastorino ${ }^{2}$ y A. Caputi ${ }^{2}$
}

1. Desarrollo y Evolución Neural, Instituto de Investigaciones Biológicas Clemente Estable, Montevideo, Uruguay.

2.Neurociencias Integrativas y Computacionales, Instituto de Investigaciones Biológicas Clemente Estable, Montevideo, Uruguay.

* Corresponding author: mcastello@iibce.edu.uy

Weakly electric fish have an electric organ which activation, the electric organ discharge (EOD) generates an electric field detected by specialized sensory organs (electroreceptors) innervated by primary electrosensory afferents that project to the brainstem. The sensory side of the electrosensory system is best known in the pulse type weakly electric Gymnotus omarorum and the wave type weakly electric Apteronotus leptorhynchus [1] but not in the related species Brachypopomus gauderio and Eigenmannia.

The self-generated electric field or "electric bubble"[2], is the carrier of active electrolocation and electrocommunication signals detected by tuberous electroreceptors -TER-. G. omarorum TER are unevenly distributed on the cutaneous surface [3] likened to an "electro-receptive retina" [4]. TER receive innervation from primary electrosensory afferents that project somatotopically to terminal fields at the electrosensory lateral line lobe [5].

Bioelectrical signals of lower intensity and frequency -produced by prays or predator's musculatureare the specific stimuli of ampullary electroreceptors (AER) involved in passive electrosensation. Neither its density and nor its distribution are known in G. omarorum.

In this work, a comparative analysis of the electrosensory periphery has been carried out in four species of Gymnotids of pulse (G. omarorum, and B. gauderio) and wave (Eigenmannia and A. leptorhynchus) types, which differ in EOD frequency

The spatial distribution of TER and AER was in skin whole mounts. TER and AER structure were studied in immunostained or silver impregnated sections. Primary afferents' terminal fields were studied by transganglionic transport of neuronal tracers.

We found a common pattern of TER spatial distribution, with maximal TER density at the rostral region of the chin, lower values at the snout, and a rostral-caudal decay along the body. Similarly, AER showed a rostra-caudal gradient except for Eigenmannia that presented highest values at the snout.

In all studied species, the electrosensory afferents projected somatotopically onto the ELL with a higher representation of the chin.

These results indicate a shared plan of organization electrosensory periphery and central projections, suggesting a shared functional organization of active and passive electrosensory system in wave and pulse type gymnotids, regardless of the EOD frequency. 
References:

[1] C. E. Carr, L. Maler, E. Sas, Peripheral organization and central projections of the electrosensory nerves in gymnotiform fish. Journal of Comparative Neurology. 211(1982), p. 139.

[2] A. C. Pereira, P. Aguilera, A. A. Caputi. The active electrosensory range of Gymnotus omarorum. Journal of Experimental Biology. 215(2012), p. 3266.

[3] M. E. Castello, P. A. Aguilera, O. Trujillo-Cenóz, A. A. Caputi, Electroreception in Gymnotus carapo: Pre-receptor processing and the distribution of electroreceptor types. Journal of Experimental Biology. 203(2000), p. 3279.

[4] H. W. Lissmann and K. E. Machin. The Mechanism of Object Location in Gymnarchus Niloticus and Similar Fish. Journal of Experimental Biology 35(1958), p. 451.

[5] 1. M. E. Castelló, A. Caputi, O. Trujillo-Cenóz, Structural and functional aspects of the fast electrosensory pathway in the electrosensory lateral line lobe of the pulse fish Gymnotus carapo. Journal of Comparative Neurology. 401(1998), p. 549.

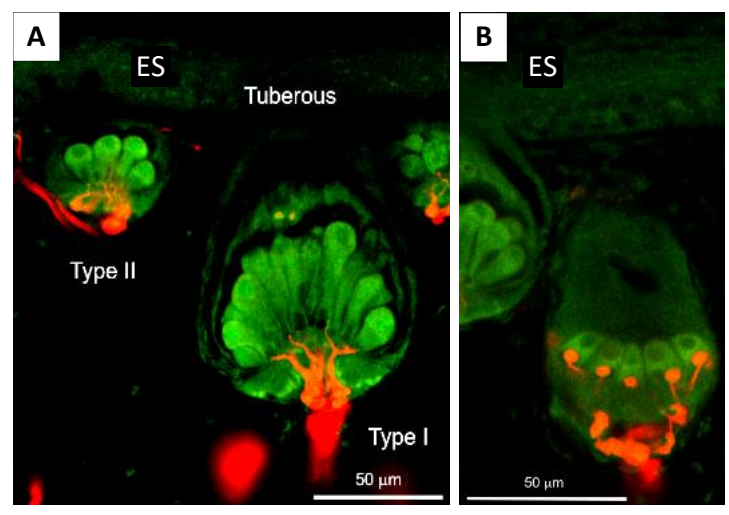

Figure 1. Electrosensory periphery. Main types of electroreceptors. A), B) Micrographs of a transverse sections through Gymnotus omarorum foveal skin to evidence ER morphology (autofluorescence, green) and pattern of innervation (mouse anti-3A10 antibody, red). A) Type I tuberous electroreceptors (I) of large diameter and are innervated by thick electrosensory afferents that give rise to thin end terminals. Type II tuberous electroreceptors (Type II), of smaller diameter, are innervated by shorter nerve branches. B) Ampullary ER consist of an ampulla of cubic electrosensory cells surrounding a central cavity contacted by electrosensory afferents that give rise to large endterminals. ES: epidermal surface.
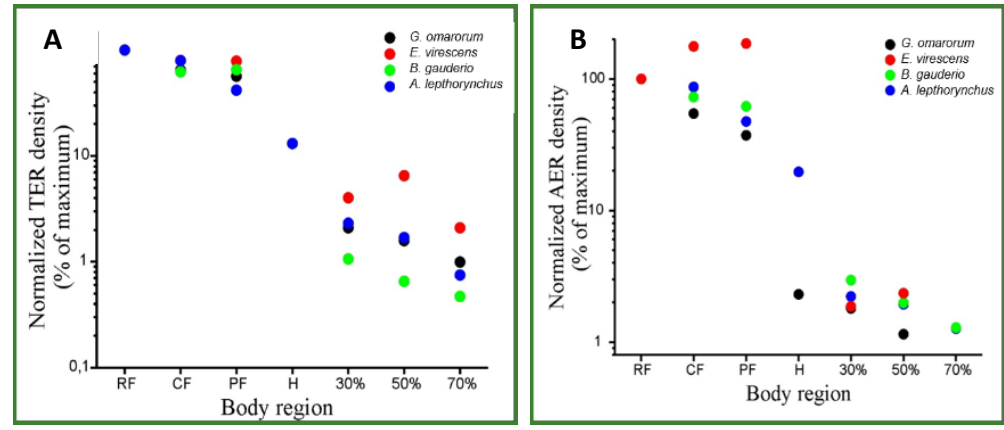

Figure 2 Spatial distribution of A) tuberous (TER) and B) ampullary (AER) electroreceptors in Pulse type (G. omarorum and B. gauderio) and wave (Eigenmannia and A. leptorhynchus) gymnotids. A) and $\mathrm{B}$ ) represent the normalized TER and AER densities (expressed as a percentage of the maximum density) as a function of the normalized distance from the snout (expressed as percentage of fish length). RF: rostral region of the chin; CF: caudal region of the chin; PF: snout; H: caudal region of the head; 30\%, 50\% and 70\%: percentages of fish length. 